\title{
Clinical Characteristics and Risk Factors of Gastrointestinal Perforation in Children with Henoch-Schönlein Purpura
}

\author{
Qingyin Guo \\ The First Affiliated Hospital of Henan University of CM \\ Xiaolei Hu \\ Henan University of Traditional Chinese Medicine \\ Chundong Song \\ The First Affiliated Hospital of Henan University of CM \\ Xianqing Ren \\ The First Affiliated Hospital of Henan University of CM

\section{Wensheng Zhai} \\ The First Affiliated Hospital of Henan University of CM \\ Ying Ding \\ The First Affiliated Hospital of Henan University of CM \\ Xia Zhang \\ The First Affiliated Hospital of Henan University of CM \\ Meng Yang \\ The First Affiliated Hospital of Henan University of CM \\ Jian Zhang \\ The First Affiliated Hospital of Henan University of CM \\ Miao Jiang ( $\square$ jiang_miao2012@163.com) \\ The First Affiliated Hospital of Henan University of CM
}

\section{Research article}

Keywords: Children, Henoch-Schonlein purpura, Gastrointestinal perforation, Retrospective analysis, Risk factors

Posted Date: June 22nd, 2020

DOI: https://doi.org/10.21203/rs.3.rs-37348/v1

License: (c) (1) This work is licensed under a Creative Commons Attribution 4.0 International License. Read Full License 


\section{Abstract}

Background: Henoch-Schönlein purpura (HSP) is a common small vessel vasculitis in children. Gastrointestinal perforation (GP) rarely presents as a complication of HSP and was not well characterized. This study aimed to investigate the clinical features, diagnosis and risk factors of GP in children with HSP.

Methods: We retrospectively reviewed the clinical data of 10791 children with HSP who attended our hospital between January 2014 and June 2018 and analyzed the treatment and clinical risk factors of 11 children with HSP complication with GP.

Results: GP occurred in 11 children with HSP, with an incidence of $0.10 \%$. Among the 11 cases HSP with GP, 1 case was gastric perforation and 10 cases were intestinal perforation. CT indicates perforation but ultrasonography did not indicate perforation in 5 cases of GP patients. The average duration of abdominal pain in HSP with GP was 9.3 days, and 9 cases (81.8\%) with a duration of abdominal pain over 7 days. 3 cases of HSP with GP were treated by gastric/intestinal perforation repair and the other 8 cases were treated by enterectomy. The type of purpura, abdominal pain lasting more than 7 days, hematochezia, renal damage, and methylprednisolone dose more than $2 \mathrm{mg} / \mathrm{kg}$ in GP with HSP patients show statistically significant compared with the control group $(P<0.05)$.

Conclusion: The incidence rate of GP in children with HSP was $0.10 \%$. Abdominal (or mixed) HSP, hematochezia, renal damage, abdominal pain lasting more than 7 days, and methylprednisolone dose more than $2 \mathrm{mg} / \mathrm{kg}$ may increase the risk of GP in children with HSP. CT has a high sensitivity for the diagnosis of GP. Early diagnosis and timely treatment of HSP with GP were very important for good clinical outcomes.

\section{Background}

Henoch-Schönlein purpura (HSP) also known as IgA vasculitis, is a systemic vasculitis based on extensive inflammation of small blood vessels and is the most common vasculitis in childhood [1]. The incidence of HSP was 20.4 per 100000 [2]. Clinical manifestations of HSP include palpable skin purpura, gastrointestinal symptoms, joint symptoms, and renal damage. HSP patients whose main clinical manifestation is gastrointestinal symptoms called abdominal type HSP. Intestinal obstruction and intestinal perforation may occur in severe cases [3, 4], if not treated or surgery immediately, it will lead to serious consequences and even death. In current, only a few publications about HSP complicated with GP, it was generally recorded as case reports in previous studies [5-7]. There still lack large sample investigation data, and no in-depth study on the risk factors related to its onset has been conducted. We herein retrospectively analyzed the clinical data of 11 cases of HSP with GP among 10791 HSP patients and analyzed clinical characteristics, diagnosis, treatment and risk factors.

\section{Methods}

A total of 10791 cases (aged 1 17 years) of children with HSP who attended the Department of Pediatrics, First Affiliated Hospital of Henan University of traditional Chinese medicine from January 2014 to June 2018 were selected as study subjects. All children diagnosed with HSP are based on the European league of rheumatology (EULAR) and the children's rheumatology international (PRINTO) and the children's rheumatology league (PRES) in 2010 [8]. Clinical data of 11 children with GP (perforation group) were collected, including gender, age, clinical manifestations, time of abdominal pain, hematochezia, renal damage and diagnosis and treatment. 42 of the 10780 HSP children without GP were selected (whose hospital admission number includes the number "111") as the control group. Gender, age, purpura type, abdominal pain duration, hematochezia, renal damage and other risk factors that may affect GP in children with HSP were analyzed. All the clinical data used in this study were obtained from the paper and electronic medical records of our hospital and approved by the medical ethics committee of the First Affiliated Hospital of Henan University of traditional Chinese medicine.

\section{HSP clinical classification}

The classification of HSP was divided into:

Skin purpura: clinical manifestations were simple skin purpura alone;

Joint type: in addition to skin purpura, joint swelling and pain symptoms;

Abdominal type: in addition to skin purpura, gastrointestinal symptoms and signs, such as abdominal pain nausea and vomiting;

Renal type: skin purpura accompanied by hematuria and/or proteinuria specific;

Mixed type: in addition to skin purpura, the other three types of two or more.

\section{Statistical analysis}

The descriptive analysis included calculations of various proportions. Chi-squared test and univariate logistic regression were used to analyze the risk factors of HSP complicated with GP. Statistical analyses were performed using SPSS statistical package 22.0 (IBM SPSS Inc., Chicago, IL, USA). A value of $p<0.05$ was considered statistically significant.

\section{Results}




\section{Age of onset in children with HSP}

A total of 10791 cases of children with HSP who attended the department of pediatrics, first affiliated hospital of Henan University of Chinese Medicine between January 2014 and June 2018, including 6278 males and 4513 females. The average age of onset was $8.07 \pm 3.18$ years. HSP mainly occurred in children aged between 3 14 years, with a total of 10194 cases, accounting for $94.47 \%$. The peak morbidity age was $5 \sim 9$ years, with a total of 6168 cases, accounting for $57.16 \%$. Detailed results are shown in Figure1.

\section{Clinical manifestations of children with HSP}

The clinical manifestations of HSP were divided skin type, joint type, abdominal type, renal type and mixed type. In this study, clinical manifestations of 10791 children with HSP were classified, as shown in Table 1, among 10791 HSP children, 1992 cases (18.46\%) only appear skin purpura, 4434 cases (41.08\%) with joint symptoms, 4357 cases (40.75\%) with abdominal symptoms, and 4072 cases $(37.72 \%)$ with renal damage.

\section{Clinical characteristics and diagnosis of GP in children with HSP}

Among 10791 HSP children, total 11 cases developed GP, the incidence was $0.10 \%$. 11 HSP children with GP, including 8 males and 3 females, 5 to 13 years old, the average age is 8.09 years. These 11 cases with GP had a lot of skin purpura accompanied with hematemesis and gastrointestinal symptoms, including 3 cases of facial skin purpura, 8 cases with joint pain, 7 cases with renal damage. Among 11 cases HSP children with GP, 1 case was gastric perforation, 10 cases were intestinal perforation; ileocecal region, terminal ileum and ileum accounted for 4 cases, 1 case and 5 cases, respectively; found the GP from abdominal pain start time minimum 3 days, the most 14 days, an average of 9.3 days. Among the 11 cases, 3 cases were diagnosed by color doppler ultrasound without $\mathrm{CT}$, three cases were all positive, five cases were negative by color doppler ultrasound, then positive by CT. Case 1 (gastric perforation), case 6 (terminal ileum perforation) and case 11 (ileum perforation) due to early detection, the patient had a small perforation and underwent gastric/intestinal repair, while the remaining 8 patients underwent enterectomy, of which case 7 had a small intestinal diverticulum and underwent diverticular resection; due to severe abdominal pollution, 4 and 5 cases underwent intestinal resection and anastomosis plus intraperitoneal fistula, and the fistula was pulled out half a year later. The clinical characteristics and diagnosis and treatment of the children with GP as shown in Table 2. CT diagnosis and surgical treatment of GP in children with HSP (case 6) are shown in Figure 2.

\section{Risk factors analysis of GP in children with HSP}

GP is one of the serious complications of HSP children, diagnosis and surgical treatment should be given in timely. To explore the risk factors of GP in HSP children, 11 cases HSP children with GP as perforation group, 42 cases from the remained 10780 cases HSP children were selected as control group. Chisquared test and univariate logistic regression were used to analyze the risk factors that might affect the occurrence of GP in HSP children, such as gender, age, purpura type, the time of abdominal pain, hematochezia, renal damage, methylprednisolone dose more than $2 \mathrm{mg} / \mathrm{kg}$. As the results showed the abdominal type (or mixed type) HSP, hematochezia, renal damage, abdominal pain lasts more than 7 days, methylprednisolone dose more than $2 \mathrm{mg} / \mathrm{kg}$ showed statistically significant differences $(p<0.05)$ (Table 3 ), which maybe the potential risk factors of GP in children with HSP.

\section{Discussion}

HSP is a commonly vasculitis in childhood. In this study, we retrospectively analyzed the clinical data of 10791 HSP children who attended our hospital between January 2014 and June 2018. Among the 10791 HSP children, 10194 cases (94.47\%) occurring at the age of 3 14 years, 6168 cases (57.16\%) occurring at the age of $5 \sim 9$ years.

Gastrointestinal symptoms were frequently observed in children with HSP, accounting for $50 \%$ 75\% [2, 3, 9], abdominal distention and abdominal pain are the usual clinical manifestations, and the pathological manifestations are erosion, edema and necrosis of gastrointestinal tract mucosa[10]. Typical endoscopic manifestations of HSP include diffuse mucosal edema, erythema and ecchymosis, or multiple irregular ulcers [11, 12]. In our study, we found 11 of the 10791 HSP children developed GP, with an incidence of $0.10 \%$, lower than that reported in the literature of $0.38 \%[13]$. To our knowledge, the reported 11 patients represent the biggest retrospective case series hitherto published.

GP is one of the abdominal complications requiring surgical treatment in HSP children. Other complications include intussusception, massive gastrointestinal bleeding and intestinal necrosis[14]. The symptoms of children with GP are relatively serious, and delayed treatment may endanger the life of the patients. Hence, we analyzed the possible risk factors of GP in HSP children, including age, gender, purpura type, the time of abdominal pain, hematochezia, renal damage, methylprednisolone dose more than $2 \mathrm{mg} / \mathrm{kg}$.

In our study, 7 HSP children with GP were associated with renal damage (63.63\%), which was significantly higher than that of the control group (26.2\%), suggesting that HSP children with renal damage had a greater risk of GP. Some studies indicate that abdominal pain may be one of the important risk factors of HSP children renal damage $[5,15]$, therefore, HSP children with gastrointestinal symptoms should be regularly monitored with routine urine, renal damage. 11 cases HSP children with GP all showed bloody symptoms (100\%), while the control group only 3 cases (7.14\%) showed bloody symptoms, indicated that bloody symptom is one risk of GP. In addition, HSP children with GP show a large number of skin purpura, and 3 cases show facial purpura. Whether the risk of GP can be identified early according to the severity of skin purpura and site symptoms remains to be further studied and confirmed. 
The pathogenesis of GP in HSP children was still unclear. It has been reported that thrombus caused by vasculitis may lead to intestinal ischemia, followed by intestinal wall necrosis and perforation [16]. Ultrasonography or CT signs are useful to confirm the diagnosis of GP. The key to ultrasonographic examination of gastrointestinal perforation is the free gas under the diaphragm and a small amount of gas and fluid next to the perforation. When the perforation is small, the subphrenic gas is less, or the intestinal perforation is wrapped by other surrounding tissue, the gas can't reach the subdiaphragm, or the patient has a large amount of air in the intestinal loop, it will affect the color ultrasound diagnosis. In our study, ultrasonography did not indicate perforation, but CT indicated perforation of gastrointestinal tract in 5 cases, suggesting that CT was more sensitive than ultrasonography. Therefore, when GP was not detected by ultrasonography but clinical symptoms can't be excluded, we should perform CT examination to avoid misdiagnosis.

In our study, the average duration of abdominal pain of GP in HSP children was 9.3 days, this was consistent with that intestinal perforation of HSP occurred during the second week after hormone application[13]. There are 9 cases (81.8\%) abdominal pain lasted more than a week, while the longest time in the control group is 5 days. HSP children abdominal pain lasting more than a week can be considered as identifying early GP reference. Glucocorticoid can reduce the edema, relieve pain, application of hormone in early stage may reduce the risk of surgical intervention[4, 15]. But systemic glucocorticoid therapy may mask symptoms of surgical complications such as abdominal pain and fever[15]. Some studies have shown that large doses of corticosteroids could reduce mucosal mucus synthesis in the gastrointestinal tract, inhibit the regeneration and healing of the intestinal mucosa, reduce the thickness of the gastrointestinal wall, and reduce lymphatic follicles, all of which increase the risk of intestinal perforation $[5,6,13,17]$. Our study indicated that a course of methylprednisolone of more than 7 days and a dose of more than $2 \mathrm{mg} / \mathrm{kg}$ were risk factors of GP in HSP children. However, hormones were still the most effective treatment options for abdominal symptoms of HSP. Therefore, in the clinical treatment of HSP patients, it is necessary to weigh the advantage and disadvantages of long-term and high-dose hormone use, and to control the dosage and course of hormone use.

\title{
Conclusions
}

HSP children with severe gastrointestinal symptoms should be evaluated for GP. In the current study, we found that the factors of abdominal or mixed HSP, abdominal pain lasting more than 7 days, hematochezia, renal damage, methylprednisolone dose more than $2 \mathrm{mg} / \mathrm{kg}$ may increase the risks of GP in HSP children. It's necessary to cooperate with physical examination and combine with color ultrasound or CT examination to identify and diagnose HSP-related gastrointestinal tract as early as possible, so as to give timely and appropriate surgical intervention measures to reduce the trauma of children. Due to GP is relatively rare in HSP children, the number of cases can be expanded or a multicenter clinical study can be conducted to further study the relationship between HSP and GP and reduce complications.

\author{
Abbreviations \\ HSP: Henoch-Schönlein purpura \\ GP: Gastrointestinal perforation \\ CT: Computerized tomography
}

\section{Declarations}

\section{Ethics approval and consent to participate}

The study protocol was approved by the Research Ethics Commission of the First Affiliated Hospital of Henan University of Chinese Medicine. This study is a retrospective analysis of pre-existing data, and the informed consent of parents or guardians is not required.

\section{Consent for publication}

The authors declare that they agree to submit the article for publication.

\section{Availability of data and materials}

The data used in this study are available upon request of the author Qingyin Guo.

The paper and electronic medical record used in this study belong to the First Affiliated Hospital of Henan University of Chinese Medicine and is available only via administrative permission.

\section{Competing interests}

The authors declare that they have no competing interests.

\section{Funding}

This work was supported by the Special Project of Chinese Medicine Scientific Research in Henan囚2016ZY2030区 


\section{Author's contributions}

All authors contributed to the study conception and design. QG, XZ, MY and MJ reviewed the medical records, analyzed and interpreted the data. CS, XR, WZ and YD coordinated and supervised data collection. XH and JZ collected data and searched literature. The first draft of the manuscript was written by QG and MJ. All authors read and approved the final manuscript.

\section{References}

1. Trnka P: Henoch-Schonlein purpura in children. Journal of paediatrics and child health 2013, 49(12):995-1003.

2. Gardner-Medwin JM, Dolezalova P, Cummins C, Southwood TR: Incidence of Henoch-Schonlein purpura, Kawasaki disease, and rare vasculitides in children of different ethnic origins. Lancet 2002, 360(9341):1197-1202.

3. Yamazaki T, Akimoto T, Iwazu Y, Sugase T, Takeshima E, Numata A, Komada T, Yoshizawa H, Otani N, Morishita Y et al: Henoch-Schonlein purpura complicated with severe gastrointestinal bleeding. CEN case reports 2015, 4(1):106-111.

4. Subspecialty Group of I, Society of P, Chinese Medical A, Editorial Board of Chinese Journal of P: [Evidence-based recommendations for the diagnosis and management in the children with Henoch-Schonlein purpura]. Zhonghua Er Ke Za Zhi 2013, 51(7):502-507.

5. Lerkvaleekul B, Treepongkaruna S, Saisawat P, Thanachatchairattana P, Angkathunyakul N, Ruangwattanapaisarn N, Vilaiyuk S: Henoch-Schonlein purpura from vasculitis to intestinal perforation: A case report and literature review. World journal of gastroenterology 2016, 22(26):6089-6094.

6. Wang HL, Liu HT, Chen Q, Gao Y, Yu KJ: Henoch-Schonlein purpura with intestinal perforation and cerebral hemorrhage: a case report. World journal of gastroenterology 2013, 19(16):2574-2577.

7. Chahri Vizcarro N, Andreu Solsona V, Barba Sopena S, Sanjaume Feixas M: Intussusception as the main manifestation of Schonlein-Henoch purpura in an adult patient. Gastroenterol Hepatol 2019, 42(7):443-444.

8. Ozen S, Pistorio A, lusan SM, Bakkaloglu A, Herlin T, Brik R, Buoncompagni A, Lazar C, Bilge I, Uziel Y et al: EULAR/PRINTO/PRES criteria for HenochSchonlein purpura, childhood polyarteritis nodosa, childhood Wegener granulomatosis and childhood Takayasu arteritis: Ankara 2008. Part II: Final classification criteria. Ann Rheum Dis 2010, 69(5):798-806.

9. Wang X, Zhu Y, Gao L, Wei S, Zhen Y, Ma Q: Henoch-Schonlein purpura with joint involvement: Analysis of 71 cases. Pediatr Rheumatol Online J 2016, 14(1):20.

10. Goda F, Maeba T, Usuki H, Karasawa Y, Izuishi K, Ishimura K, Senda S, Maeta H: Colo-colic intussusception associated with Henoch-Schonlein purpura in adults. J Gastroenterol Hepatol 2007, 22(3):449-452.

11. Louie CY, Gomez AJ, Sibley RK, Bass D, Longacre TA: Histologic Features of Gastrointestinal Tract Biopsies in IgA Vasculitis (Henoch-Schonlein Purpura). Am J Surg Pathol 2018, 42(4):529-533.

12. Audemard-Verger A, Pillebout E, Guillevin L, Thervet E, Terrier B: IgA vasculitis (Henoch-Shonlein purpura) in adults: Diagnostic and therapeutic aspects Autoimmun Rev 2015, 14(7):579-585.

13. Yavuz H, Arslan A: Henoch-Schonlein purpura-related intestinal perforation: a steroid complication? Pediatrics international : official journal of the Japan Pediatric Society 2001, 43(4):423-425.

14. Shiohama T, Kitazawa K, Omura K, Honda A, Kozuki A, Tanaka N, Omata A, Ooe K, Suzuki Y: Intussusception and spontaneous ileal perforation in HenochSchonlein purpura. Pediatrics international : official journal of the Japan Pediatric Society 2008, 50(5):709-710.

15. van den Broek RW, van Rossum MA, van Duinen CM: A new surgical complication related to corticosteroids in a patient with Henoch-Schonlein purpura. $J$ Pediatr Surg 1995, 30(9):1341-1343.

16. Choong CK, Beasley SW: Intra-abdominal manifestations of Henoch-Schonlein purpura. Journal of paediatrics and child health 1998, 34(5):405-409.

17. Almassinokiani F, Mehdizadeh Kashi A, Musavi A, Khodaverdi S, Tahermanesh K, Ariana S: Rectal perforation in a 42-year-old woman due to HenochSchonlein purpura: a case report. Reumatismo 2017, 69(3):131-133.

\section{Tables}

Table 1. Clinical manifestations of children with HSP

\begin{tabular}{|c|c|c|c|c|c|c|c|c|}
\hline \multirow{2}{*}{$\begin{array}{l}\text { Clinical } \\
\text { manifestation }\end{array}$} & \multirow[t]{2}{*}{ Skin } & \multirow[t]{2}{*}{ Joint } & \multirow[t]{2}{*}{ Abdominal } & \multirow[t]{2}{*}{ Renal } & \multicolumn{4}{|l|}{ Mixed } \\
\hline & & & & & Abdominal + Renal & Abdominal + Joint & Joint + Renal & Abdominal + Renal + Joint \\
\hline No. of cases & 1992 & 2206 & 1523 & 1715 & 1117 & 988 & 511 & 729 \\
\hline Percent $₫ \% \bigotimes$ & 18.46 & 20.44 & 14.11 & 15.89 & 10.35 & 9.16 & 4.73 & 6.75 \\
\hline
\end{tabular}


Table 2. Clinical characteristics, diagnosis and treatment of HSP complicated with GP

\begin{tabular}{|c|c|c|c|c|c|c|c|c|c|c|c|c|}
\hline No. & Sex & Age & $\begin{array}{l}\text { Days of } \\
\text { abdominal } \\
\text { pain }\end{array}$ & CT & Ultrasound & Diagnosis & Site & Treatment method & $\begin{array}{l}\text { Facial } \\
\text { purpura }\end{array}$ & $\begin{array}{l}\text { Joint } \\
\text { pain }\end{array}$ & $\begin{array}{l}\text { Renal } \\
\text { damage }\end{array}$ & $\begin{array}{l}\text { Methylprednisc } \\
\text { dose and durat }\end{array}$ \\
\hline 1 & Male & 13 & 16 & + & - & $\begin{array}{l}\text { gastric } \\
\text { perforation }\end{array}$ & gastral & $\begin{array}{l}\text { Intestinal } \\
\text { perforation repair }\end{array}$ & - & + & - & $\begin{array}{l}3 \mathrm{mg} / \mathrm{kg} / \mathrm{day} \text { fo } \\
\text { days }\end{array}$ \\
\hline 2 & Male & 6 & 9 & / & + & $\begin{array}{l}\text { intestinal } \\
\text { perforation }\end{array}$ & ileocecal & Enterectomy & - & - & + & $\begin{array}{l}2.5 \mathrm{mg} / \mathrm{kg} / \mathrm{day} \\
\text { days }\end{array}$ \\
\hline 3 & Female & 5 & 16 & + & - & $\begin{array}{l}\text { intestinal } \\
\text { perforation }\end{array}$ & ileocecal & Enterectomy & + & + & + & $\begin{array}{l}2.4 \mathrm{mg} / \mathrm{kg} / \mathrm{day} \\
17 \text { days }\end{array}$ \\
\hline 4 & Female & 5 & 11 & + & + & $\begin{array}{l}\text { intestinal } \\
\text { perforation }\end{array}$ & ileocecal & Enterectomy+fistula & - & + & + & $\begin{array}{l}3 \mathrm{mg} / \mathrm{kg} / \text { day fo } \\
\text { days }\end{array}$ \\
\hline 5 & Female & 7 & 7 & / & + & $\begin{array}{l}\text { intestinal } \\
\text { perforation }\end{array}$ & ileocecal & Enterectomy+fistula & - & - & + & $\begin{array}{l}2.5 \mathrm{mg} / \mathrm{kg} / \mathrm{day} \\
30 \text { days }\end{array}$ \\
\hline 6 & Male & 8 & 11 & + & - & $\begin{array}{l}\text { intestinal } \\
\text { perforation }\end{array}$ & $\begin{array}{l}\text { terminal } \\
\text { ileum }\end{array}$ & $\begin{array}{l}\text { Intestinal } \\
\text { perforation repair }\end{array}$ & - & + & - & $\begin{array}{l}2.8 \mathrm{mg} / \mathrm{kg} / \mathrm{day} \\
11 \text { days }\end{array}$ \\
\hline 7 & Male & 12 & 11 & + & - & $\begin{array}{l}\text { intestinal } \\
\text { perforation }\end{array}$ & ileum & $\begin{array}{l}\text { Enterectomy + } \\
\text { diverticulectomy }\end{array}$ & + & + & + & $\begin{array}{l}2.3 \mathrm{mg} / \mathrm{kg} / \mathrm{day} \\
11 \text { days }\end{array}$ \\
\hline 8 & Male & 9 & 3 & / & + & $\begin{array}{l}\text { intestinal } \\
\text { perforation }\end{array}$ & ileum & Enterectomy & - & + & - & $\begin{array}{l}2.9 \mathrm{mg} / \mathrm{kg} / \mathrm{day} \\
\text { days }\end{array}$ \\
\hline 9 & Male & 10 & 14 & + & - & $\begin{array}{l}\text { intestinal } \\
\text { perforation }\end{array}$ & ileum & Enterectomy & - & + & - & $\begin{array}{l}3.2 \mathrm{mg} / \mathrm{kg} / \text { day } \\
14 \text { days }\end{array}$ \\
\hline 10 & Male & 7 & 5 & + & + & $\begin{array}{l}\text { intestinal } \\
\text { perforation }\end{array}$ & ileum & Enterectomy & - & + & + & $\begin{array}{l}3 \mathrm{mg} / \mathrm{kg} / \text { day fo } \\
\text { days }\end{array}$ \\
\hline 11 & Male & 7 & 9 & + & + & $\begin{array}{l}\text { intestinal } \\
\text { perforation }\end{array}$ & ileum & $\begin{array}{l}\text { Intestinal } \\
\text { perforation repair }\end{array}$ & + & - & + & $\begin{array}{l}3 \mathrm{mg} / \mathrm{kg} / \mathrm{day} \text { fo } \\
\text { days }\end{array}$ \\
\hline
\end{tabular}

Note: "+" means positive, "-" means negative, "/" means no test

Table 3. The univariate Chi-square test of risk factors of HSP with GP $[n(\%)]$

\begin{tabular}{|lllllllll|}
\hline group & $\begin{array}{l}\text { Case } \\
\text { number }\end{array}$ & $\begin{array}{l}\text { Age<10 } \\
\text { years }\end{array}$ & Male & $\begin{array}{l}\text { Abdominal (mixed) } \\
\text { allergic purpura }\end{array}$ & Hematochezia & $\begin{array}{l}\text { Renal } \\
\text { damage }\end{array}$ & $\begin{array}{l}\text { Abdominal pain lasts } \\
\text { longer than } 7 \text { days }\end{array}$ & $\begin{array}{l}\text { Methylprednisolone } \\
\text { dose more than 2mg/kg }\end{array}$ \\
\hline $\begin{array}{l}\text { Perforated } \\
\text { group }\end{array}$ & 11 & $9(81.8)$ & $8(72.7)$ & $11(100.0)$ & $11(100.0)$ & $7(63.6)$ & $9(81.8)$ & $11(100)$ \\
\hline Control & 42 & $35(83.3)$ & $28(66.7)$ & $27(64.3)$ & $3(7.14)$ & $11(26.2)$ & $0(0)$ & $3(7.14)$ \\
\hline$\chi^{2}$ value & & 0.014 & 0.147 & 5.479 & 38.668 & 5.449 & 41.39 & 38.67 \\
\hline$P$ value & & 0.905 & 0.701 & 0.019 & 0 & 0.019 & 0 \\
\hline
\end{tabular}

\section{Figures}

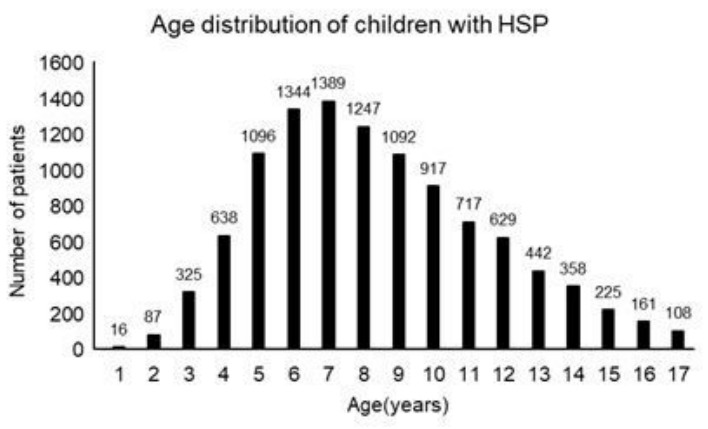

Figure 1

Age distribution of children with HSP 

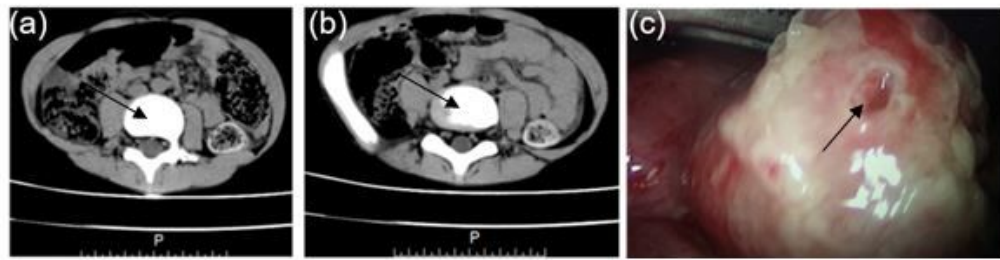

\section{Figure 2}

CT diagnosis and treatment of HSP complicated with GP. a and b, CT image of HSP complicated with GP (case 6); c, Intraoperative image of HSP complicated with GP (case 6). Arrows indicate perforation of the digestive tract. 